\title{
Penelusuran Ideologi Dalam Novel Ayat-Ayat Cinta: Sebuah Analisis Tematis dan Estetis
}

\author{
Rohim \\ Pusat Bahasa, Kementerian Pendidikan Nasional
}

\begin{abstract}
Abstrak: Seorang sastrawan dapat mengekspresikan semestanya dalam sebuah karya sastra. Semua yang ia tuangkan dalam teks sastra merupakan gagasan-gagasan yang ingin ia katakan kepada pembacanya. Kumpulan gagasan tersebut bisa dikatakan sebagai ideologi, setidaknya ideologi pengarang. Hadirnya ideologi bertujuan untuk menawarkan perubahan, memperbaiki tatanan yang sudah ada, atau bahkan merubah total kebiasaan yang sudah menahun. Ideologi yang dituangkan dalam karya sastra mempunyai 'tangan' yang dapat mengubah proses kehidupan melalui ungkapan dan gagasan pengarang. Hal demikian salah satunya dapat terlihat dari gagasan-gagasan yang terkandung dalam novel AyatAyat Cinta, memberikan gambaran yang sesungguhnya tentang bagaimana ajaran Islam yang kaffah jika bersinggungan dengan realitas sosial yang kompleks. Selain gagasan dari novel tersebut, tulisan ini juga mengungkap nilai-nilai estetisnya.
\end{abstract}

Kata Kunci: sastra, ideologi, tematis, dan estetis

\begin{abstract}
A writer can express his universe of mind in a literary work. Everything he pours out in literary text are the ideas he would like to share to the readers. Such collection of ideas can be seen as an ideology, at least the ideology of the writer. The presence of ideology is aimed to offer changes, improve the exixtent system, or even extremely change a culture. An ideology which is expressed in a literary work has "hands", which can change the life process through the writer's ideas and expressions. This can be seen in the ideas implied in the novel "Ayat-ayat cinta"/ The Verses of love, which give a real picture of how a "thorough" islamic teaching gets conflicted with a complex social realities. In addition to the ideas implied, this essay will also disclose the esthetic side of the novels.
\end{abstract}

Key words: literary, ideology, thematic, and esthetic.

\section{Pendahuluan}

Karya sastra dasawarsa 1980-an ditandai dengan bermunculannya roman percintaan dari beberapa sastrawan wanita yang menonjol pada masa itu. Pada umumnya, tokoh yang dihadirkan dalam karya sastra terutama cerpen dan novel adalah perempuan. Hal itu bertolak belakang dengan karya sastra Balai Pustaka yang masih dipengaruhi sastra Eropa, di mana tokoh utamanya selalu 'dimatikan' untuk menonjolkan romantisme dan idealisme. Pada era 80 sampai 90-an tumbuh sastra yang beraliran pop, ditandai dengan lahirnya sejumlah novel populer yang berimplikasi baik terhadap meningkatnya minat baca masyarakat terhadap sastra terutama di kalangan anak muda. Karya sastra pada era 90-an hadir dengan tema yang lebih berat pengapresiasiannya karena pengaruh budaya Barat dan konflikkonflik terhadap sastra Indonesia. Fenomena seperti ini terus terjadi dan bahkan berkembang sampai era 2000-an. Pada dekade ini muncul salah satu komunitas sastra yang 'menggegerkan' ditandai dengan lahirnya 'sastra wangi' yang dipelopori Ayu Utami dengan salah satu karyanya Saman. Bahkan karyanya ini dikatakan sebagai awal bangkitnya kembali sastra Indonesia setelah hampir 20 tahun 'tidur dalam kulkas'. Gaya penulisan Ayu Utami yang terbuka, bahkan vulgar itulah yang membuatnya menonjol dibandingkan pengarang-pengarang lain.

Kebangkitan dan kegairahan sastra Indonesia era 2000-an tidak hanya ditunjukkan oleh kelompok 'sastra wangi' di atas, tetapi juga timbul dari penulis-penulis muda yang tergabung dalam komunitas Forum Lingkar Pena (FLP) yang karyakaryanya tidak kalah laris dibanding karya Ayu Utami atau Djenar Maesa Ayu, bahkan hal itu terjadi ketika para sastrawan beraliran liberal 
mendapatkan dukungan sepenuhnya dari media massa dan organisasi kebudayaan, sementara sastrawan FLP kurang mendapat perhatian. Salah satu bukti jawaban nyata dari FLP adalah terbitnya novel Ayat-Ayat Cinta dari salah seorang penulis komunitas tersebut, sebagai representasi kehadiran moral dalam menolak pornografi dan penggunaan kosakata yang seronok dalam karya sastra.

Tampak dalam periode ini, terdapat dua kubu yang saling 'berlawanan' ideologi dalam menghadirkan karya sastra di kalangan pembacanya untuk menjadi lebih dominan dibanding kelompok lain pada zamannya. Apakah sastra yang berkisah tentang kehidupan seks bebas dan homoseksualitas lebih bermoral dibanding kisah poligami? Ini memang sangat absurd, sah saja diikuti oleh siapa pun, dan ke mana pun, mengingat sastra, seperti yang dikemukakan oleh Roekminto (2008: 3), tidak hanya berhenti pada teks yang mati tetapi mempunyai potensi luar biasa besar untuk memengaruhi cara berpikir dan bertindak manusia.

Perbedaan atau persamaan ideologi ini sangat bergantung pada kemampuan intelektual dan periode; termasuk lingkungan pelaku sastra tersebut. Abrams (1981: 178) mengungkapkan bahwa karya sastra itu mencerminkan masyarakatnya dan secara tidak terhindarkan dipersiapkan oleh keadaan masyarakat dan kekuatan-kekuatan pada zamannya. Dengan demikian, situasi tertentu dan pada suatu zaman tertentu akan memengaruhi corak, ideologi dan gaya bersastra seseorang. Bahkan Pradopo (1987: 94) secara eksplisit mengungkap bahwa tiap generasi atau periode sastra senantiasa membawa gayanya masing-masing yang khas dan unik dan berbeda dari periode sastra yang lainnya.

Dengan latar belakang sebagaimana dikemukakan di atas, hadirnya tulisan ini akan mengkaji dan menelusuri ideologi dalam novel Ayat-Ayat Cinta karya Habiburrahman El Shirazy yang diperoleh dari pembacaan karya melalui tema karya sastra dan difokuskan pada kekhasan karya sastra itu sebagai salah satu best seller dalam periode tahun 2000-an. Selain ideologi yang terdapat dalam karya, akan diungkap juga hasil dan pencapaian dari aspek tematik dan estetiknya.
Masalah yang akan dikaji dalam tulisan ini mencakupi beberapa hal sebagai berikut: 1) bagaimana warna/dasar ideologi yang diangkat dalam novel tersebut? Apakah bersifat keagamaan, kapitalisme, marxisme, gender, atau yang lainnya; 2) bagaimana ideologi itu disuarakan/dipresentasikan? dan 3) bagaimana hasil dan pencapaian nilai estetisnya?

Fokus tulisan ini adalah karya sastra prosa yang terbit pada dekade tahun 2000-an dan mempunyai label best seller, salah satunya novel Ayat-Ayat Cinta karya Habiburrahman El Shirazy, sehingga tujuan penulisan artikel ini dimaksudklan agar dapat dipetakan ideologi-ideologi yang terdapat dalam prosa tersebut sebagai tujuan utama penulisan ini.

\section{Kajian Literatur dan Pembahasan}

Sastra sebagai suatu kesatuan pada dasarnya bersifat sistemik, sehingga antara subsistem sastra yang satu dengan yang lain saling berkaitan. Oleh karena itu, sebuah karya sastra tidak dapat terpisahkan dari konvensi imaji yang secara langsung atau tidak langsung terkait dengan lingkungan sosiokultural, tradisi prosa, dan seterusnya. Walaupun fokus penelitian karya sastra adalah bahasa teksnya itu sendiri sebagai lambang atau simbol imajinatif, akan tetapi alat yang digunakan dalam menganalisanya berbentuk teori yang dapat digunakan dalam mengungkapkan komunikasi isi hati kepada penikmatnya.

Unsur yang sangat penting dari sebuah karya sastra adalah tema. Tema menjadi dasar bagi pengarang untuk dapat mengembangkan cerita dalam memasukkan ide, gagasan atau cita-citanya secara bebas dan terpadu (Pudji Santosa, 1987: 27). Kebebasan pengarang dalam mengungkapkan idenya tidak dibatasi oleh batasan apapun, akan tetapi tema dari gagasan itu mencerminkan, bahkan dipengaruhi oleh keadaan lingkungan pada saat si pengarang menuangkan idenya. Selain dipengaruhi lingkungan pengarang, karya sastra, khususnya novel juga sangat bergantung kepada unsur-unsur yang membangunnya yang bersifat formalis, antara lain tema, amanat, alur cerita, latar cerita, dan tokoh cerita.

Imajinasi pengarang yang dituangkan dalam teks sastra akan dianalisis sedemikian rupa melalui teori, sehingga menghasilkan sebuah 
interpretasi dalam bentuk tema. Dari tema yang ditemukan akan diketahui ideologi yang digunakan si pengarang. Namun demikian, haruskah sastra berideologi? Pertanyaan tersebut tidak memerlukan jawaban"ya" atau "tidak", tetapi harus dipahami bahwa sastra mesti dicerna secara terintegrasi, antara karya sastra itu sendiri, pembaca, penulis, sejarah sastra, teori sastra, dan kritik sastra. Ideologi sebagaimana ditulis Roekminto (2008: 2) mengacu pada cara berpikir orang dan kelompok tertentu sehingga apabila seorang sastrawan yang mengekspresikan semestanya dalam sebuah karya sastra, maka apa yang dia tuangkan dalam teks itu adalah apa yang ingin ia katakan, termasuk di dalamnya ideologi yang ia anut, dan dengan sendirinya karya sastra itu sendiri sudah berideologi, setidaknya ideologi pengarang.

Dari definisi di atas mendukung pendapat yang menyatakan bahwa ideologi adalah sebagai visi pengarang yang menyeluruh dalam memandang segala sesuatu secara umum dan apa adanya bersumberkan realita kehidupan seharihari (http://id.wikipedia.org/). Dari realitas tersebut muncul berbagai gagasan atau ide sebagai bahan penguat terciptanya suatu karya. Hadirnya ideologi dalam karya sastra bertujuan untuk menawarkan perubahan, memperbaiki tatanan yang sudah ada, atau bahkan merubah total kebiasaan. Hal ini lumrah terjadi dalam kehidupan sehari-hari, mengingat kehidupan realita adalah sebuah proses panjang, dan sebuah proses tidak ada yang sempurna dan utuh. Karya sastra mempunyai 'tangan' yang bisa merubah proses itu lewat ungkapan atau gagasan penulisnya. Namun demikian, tidak berarti sastrawan menulis karya karena tujuan propaganda ideologi yang dianutnya. Jika hal ini terjadi, maka pada saat itu juga esensi sastra hilang. Karya sastra adalah sebuah ruang yang dibentangkan untuk meletakkan sebagian realitas kemanusiaan penulis atas keberadaannya. Ruang bukanlah alat, tetapi akan berubah menjadi alat ketika terjadi pemaknaan. Sedang pemaknaan itu sendiri tidak berada di tangan penulis melainkan pembaca, entah itu berkelompok, individu, atau penguasa sekali pun.

Bahkan dalam sejarahnya, ideologi sastra dan penguasa pernah saling 'bermusuhan'. Sastra di beberapa negara menjadi momok yang menakutkan bagi penguasa, padahal karya itu mendapat berbagai penghargaan. Doctor Zhivago, misalnya, sebuah karya dari Boris Pasternak dari Rusia pada masa kejayaan Stalin, karena dipandang menyimpang dari sudut pandang penguasa dan mengganggu kekuasaan, ia disingkirkan dari negaranya. Demikian pula realitas seperti di Rusia pernah terjadi di Indonesia. Wiji Thukul, Pramoedya Ananta Toer, dan beberapa sastrawan Lekra pernah mendapatkan intimidasi dari negaranya sendiri. Dalam kasus-kasus tadi, karya sastra diartikan sebagai alat yang mengarahkan perusakkan kejayaan, ia dianggap mampu menghancurkan tatanan kekuasaan negara, sehingga sikap-sikap intimidasi individu dan karya sastra pun dimunculkan oleh pemerintah. Sebagai pencipta, pengarang akan mengeksplorasikan ideologi yang tertanam di kepalanya dalam karya sastranya. Menciptakan karya sastra seolah memberikan pandangan keberadaan lingkungan sekitarnya melalui ideologi yang digunakan, terlepas apa pun ideologi tersebut. Ideologi tidak selamanya merupakan sesuatu yang harus berada pada politik kekuasaan pemerintah.

Sebagai sebuah wadah atas gagasangagasan yang harus dikomunikasikan dan dibagikan kepada manusia lain, ideologi membutuhkan sebuah media dalam melakukan proses komunikasi ini, sastra salah satunya dan dari sinilah kemudian ruang berubah menjadi alat karena sastra dipahami sebagai praksis.

\section{Sumber Data dan Sampel}

Sumber data dalam penelitian ini adalah karya sastra berupa prosa yang terbit pada dekade 2000-an yang dipilih dan dinyatakan mempunyai reputasi yang 'menggegerkan' pada masa tersebut lewat kelarisannya dalam peluncuran ke publik atau pembacanya.Sampel penelitian diambil secara acak dari teks novel Ayat-Ayat Cinta yang mempunyai nilai estetik tinggi sebagai bahan penelitian. Sampel akan dibatasi karena disesuaikan dengan kebutuhan dan tujuan yang diharapkan. 


\section{Metode dan Teknik}

Penelitian ini menggunakan metode deskriptif analitik, dan teknik pengumpulan datanya dilakukan dengan penganalisisan data karya sastra dan pencatatan pustaka.

\section{Ikhtisar ideologi dalam novel ayat-ayat cinta}

Istilah ikhtisar bermakna pendapat atau pandangan secara umum dan ringkasan dari suatu cerita. Sebuah ringkasan dapat memunculkan suatu nilai bermakna dari sebuah karya, dan nilai yang dimaksud adalah ideologi karya sastra. Karya sastra diciptakan pengarang tentu mempunyai tujuan yang hendak dicapai, salah satunya perubahan cara pandang atau kebiasaan masyarakat yang dianggap sebagai norma. Nilai yang tercantum dalam novel Ayat-Ayat Cinta karya Habiburrahman El Shirazy merupakan salah satu contoh bantahan terhadap cara pandang masyarakat, terutama dunia Barat terhadap Islam dalam melihat masalah-masalah fiqih dihubungkan dengan sosial kemasyarakatan.

Pandangan dunia Barat terhadap Islam akhirakhir ini cenderung memojokkan umat Islam sendiri, karena tingkah laku umat Islam itu selalu identik dengan berbuat kerusakkan dan berada dalam posisi yang dirugikan. Hal ini tentu tidak benar seluruhnya, dan kalau pun ada yang berbuat demikian semata karena pemahaman umat yang berbeda dalam menginterpretasi sebuah ketentuan yang baku secara radikal bahkan bertolak belakang dengan akhlak Islam itu sendiri.

Akhlak Islam yang sesungguhnya adalah AlQur'an dan Sunnah, dan menu utama novel ini adalah dua perundangan tadi ditambah dengan ijtima dan kiasan-kiasan dari para ulama. Seorang mantan peragawati muslimah, Ratih Sang mengapresiasi novel ini secara serius dan mengatakan "membaca Ayat-Ayat Cinta ini membuat angan kita melayang-layang ke negeri seribu menara dan merasakan 'pelangi' akhlak yang menghiasi pesona-pesonanya. Sungguh sebuah cerita yang layak dibaca dan disosialisasikan pada para pemburu bacaan popular yang sudah tidak mengindahkan akhlak sebagai menu utamanya, agar dunia bacaan kita terhiasi karya-karya yang membangun".
Tak ayal lagi, novel Ayat-Ayat Cinta yang dibuat sama judul dengan versi filmnya, dapat 'menyahuti' doktrin klasik sastra, bahwa yang terpenting bukanlah jalan cerita, tetapi gagasan apa yang hendak disampaikan ke masyarakat seperti yang diungkap di atas. Novel Ayat-Ayat Cinta adalah novel dakwah yang gagasan utamanya superioritas Islam, di samping tema kesesuaian Islam dengan tuntutan kekinian dan penekanan bahwa Islam bukan agama kekerasan. Superioritas Islam atas agama lain jelas terlihat pada adegan tokoh Maria yang beragama Kristen Koptik bermimpi tidak bisa masuk surga karena bukan seorang Muslim. Demikian pula superioritas Islam terlihat dalam kasus Alicia, seorang wartawati Amerika memeluk agama Islam.

Sebagai gambaran yang lebih jelas tentang gagasan atau ideologi yang terdapat dalam novel Ayat-Ayat Cinta karya Habiburrahman El Shirazy tadi, berikut akan dipaparkan beberapa di antaranya disertai dengan intertektualitas yang menguatkan ideologi tersebut dari berbagai rujukkan.

\section{Ideologi Gender}

Mengutip dari pernyataan Melani Budianta dalam majalah Horison (1998:6), gender dapat didefinisikan sebagai pembedaan-pembedaan yang bersifat sosial, yang dikenakan atas perbedaan-perbedaan biologis atau perbedaan yang nampak antara jenis-jenis kelamin. Selain pembedaan yang bersifat sosial, ia juga dihadapkan pada sesuatu pembedaan yang bersifat alami, yaitu pembedaan biologis. Gender dalam persepsi yang terdapat dalam Women's Studies Encyclopedia didefinisikan sebagai suatu konsep kultural yang berupaya membuat pembedaan (distinction) dalam hal peran, perilaku, mentalitas dan karakteristik emosional antara lakilaki dan perempuan yang berkembang dalam masyarakat (http://violetatniyamani. blogspot. com/2008/01).

Dari dua definisi di atas dapat disimpulkan bahwa gender adalah suatu konsep yang digunakan untuk mengidentifikasi perbedaan lakilaki dan perempuan dari sudut nonbiologis. Hal ini berbeda dengan sex yang secara umum digunakan untuk mengidentifikasi perbedaan lakilaki dan perempuan dari segi anatomi biologi. 
Istilah sex lebih banyak berkonsentrasi pada aspek biologis seseorang yang meliputi perbedaan komposisi kimia dan hormon dalam tubuh, anatomi fisik, reproduksi dan karakteristik biologis lainnya. Sementara itu, gender lebih banyak berkonsentrasi pada aspek sosial, budaya, psikologis dan aspek-aspek nonbiologis lainnya. Studi gender lebih menekankan perkembangan maskulinitas atau feminitas seseorang. Sedangkan studi sex lebih menekankan perkembangan aspek biologis dan komposisi kimia dalam tubuh laki-laki dan perempuan. Untuk proses pertumbuhan anak kecil menjadi seorang laki-laki atau menjadi seorang perempuan, lebih banyak digunakan istilah gender daripada istilah seks. Istilah seks umumnya digunakan untuk merujuk kepada persoalan reproduksi dan aktivitas seksual, selebihnya digunakan istilah gender.

Dalam novel Ayat-Ayat Cinta terlihat jelas sebuah sekenario yang merepresentasikan gagasan 'penggugatan' terhadap ketertindasan seorang perempuan lewat tokoh Noura yang dilakukan oleh ayah angkatnya, Bahadur. Melalui naratornya yang berperan sebagai Fahri, dalam novel ini digambarkan bagaimana dunia seorang anak perempuan yang tengah beranjak dewasa diperlakukan oleh ayah angkatnya sebagai 'sumber mata pencaharian' demi memenuhi hasrat dan kesenangan hidup keluarga.

Yang menjadi fokus perhatian pembaca dalam melihat adegan ini adalah tokoh Noura itu sendiri dan naratornya. Noura seorang gadis mesir keturunan Palestina memang seorang sosok perempuan yang benar-benar membuat orang terpesona melihat kecantikannya. Kecantikannya telah dimanfaatkan oleh ayah yang tidak bertanggungjawab untuk diperjual belikan kepada pria hidung belang berkantong tebal. Sebagai seorang siswa tingkat akhir di Ma'had Al Azhar putri, ia merasa jijik dan risi atas keinginan ayahnya. Berbagai macam cara halus ia lakukan untuk menolak keinginan ayahnya, tetapi tetap saja tidak berhasil meluluhkan hati ayah yang dihinggapi pengaruh uang dan minuman keras. Pembangkangan pun ia lakukan secara terangterangan dengan risiko disiksa dan diperlakukan seperti binatang tak bernilai sedikit pun.

Sebagai pembaca karya, melalui ironi dramatis melihat adanya kesenjangan antara visi narator dan tatanan nilai kemasyarakatan di kalangan kaum pinggiran. Budaya mabukmabukan sebagai pengaruh lingkungan pekerjaan ayah Noura membuat norma tidak diindahkan lagi. Kesenjangan ini sangat kontras dan berlawanan dengan pandangan narator yang tinggal dalam satu flat bersebelahan dengan rumah Noura.

Narator yang diperankan oleh sosok Fahri adalah seorang pemuda Indonesia tampan dan cerdas dalam menghadapi kehidupan di kampus atau di flatnya, sehingga ia ditunjuk sebagai kepala asrama oleh teman-temannya. Kecerdasannya dalam menanggapi masalah, terutama yang berhubungan dengan penindasan terhadap perempuan sangat terkesan ketika menyuruh Maria untuk turun ke bawah asrama menghampiri Noura. Kenapa Maria yang disuruh, bukan dirinya sendiri yang langsung turun menolong Noura? adalah salah satu jawaban dan bukti kecerdasan intelektualnya.

Masalah akan muncul lebih besar seandainya narator terlibat langsung dalam proses 'pembebasan' Noura dari cengkraman Bahadur. Salah satu pertimbangan narator dalam menolong gadis tertindas itu adalah pertimbangan budaya yang berlaku di daerah itu, dan norma agama. Atas kedua dasar itu Fahri menggunakan beberapa teman wanita terdekatnya untuk menolong Noura dari penindasan yang dilakukan ayahnya. Noura dititipkan di suatu tempat yang aman tidak terdeteksi keberadaannya oleh Bahadur, sambil 'dipupuk' dan 'ditanami' kembali keadaan ruhaninya yang terguncang selama dalam penyiksaan.

Penindasan terhadap perempuan lemah yang dilakukan oleh seorang laki-laki bertubuh kekar dengan sewenang-wenang dan sebebasbebasnya menyadarkan Fahri akan timbulnya simpatik keagamaan dan kemanusiaan. Kebebasan Noura telah dirampas secara paksa oleh Bahadur, Fahri berusaha sekuat tenaga untuk mengembalikan kebebasan itu demi terlihatnya kembali sinar terang jalan kehidupannya. Menanggapi hal demikian Noura merasa hidup belum akan berakhir, masih ada harapan yang bisa dicapai dan memungkinkan untuk memiliki harapan dan yang memberi harapan itu (AAC, 168). 
Sampai pada akhir alur cerita tentang penindasan terhadap perempuan yang dilakukan oleh seorang laki-laki ini, Noura mengetahui bahwa dirinya bukan anak kandung Bahadur, ia tertukar dengan bayi anak Bahadur saat dilahirkan dan dirawat di rumah sakit. Dalam akhir alur ini, pembaca disuguhkan sesuatu yang mengejutkan datang dari Noura. Noura mengaku di depan pengadilan telah diperkosa hingga hamil oleh Fahri. Suatu pengakuan yang mendatangkan kekecewaan teman-teman Fahri yang ikut andil menolong Noura dari keganasan Bahadur. Tetapi akhirnya hati Noura benar-benar bagai tertusuk pisau yang sangat tajam setelah mendengar kesaksian Maria, sehingga mengakui bahwa semua dilakukan atas rekayasa Bahadur dan dendam asmara dirinya kepada Fahri.

Contoh lain dari novel Ayat-Ayat Cinta yang mengangkat permasalahan moral yang berhubungan dengan ideologi gender adalah kasus pemerkosaan. Hampir seratus persen korban perkosaan adalah perempuan dan pelaku pemerkosaan adalah laki-laki. Perempuan selalu menjadi korban dan berada dalam posisi yang dirugikan jika kasus pemerkosaan dilakukan oleh orang yang berpengaruh atau bermodal besar. Hal ini terlihat dalam salah satu plot di novel ini, yaitu setelah beberapa hari Fahri dijebloskan ke penjara, istrinya, Aisha, walaupun diceritakan tidak terjadi perkosaan, tetapi hal ini sudah cukup memberikan gambaran kepada pembaca bahwa kasus perkosaan merupakan pelecehan fisik dan moral kepada perempuan.

Seorang petugas kepolisian yang punya pengaruh besar tergoda melihat kecantikkan Aisha, apalagi dalam keadaan sendiri di rumah ditinggal suami, berada dalam penjara. Dengan berbagai dalih kepentingan kelengkapan pemeriksaan suaminya, polisi itu bisa masuk ke rumah Aisha bermaksud untuk memperkosanya, tetapi niatnya tidak kesampaian karena diketahui dan diselamatkan oleh sekurity flat yang selalu salat berjamaah bersama Fahri (AAC, 323).

Pesan yang disisipkan narator kepada pembaca dalam kasus perkosaan adalah harga diri merupakan harga mati, dan kemuliaan perempuan sangat diagungkan. Apalagi perempuan yang hendak diperkosa tersebut seorang istri narator, bertambah mendidih darah mendengar berita yang disampaikan Magdi di atas. Seorang istri beserta atribut keibuannya adalah merupakan salah satu konstruksi gender yang paling mendapat representasi positif dalam berbagai macam wacana: keagamaan, politik, maupun budaya. Banyak karya sastra yang menggunakan ikon ibu yang sangat diagungkan itu sebagai sebuah naluri keibuan yang rela berkorban dan tanpa pamrih.

Simbol tentang keibuan ini pada kenyataannya dalam beberapa karya sastra; prosa, puisi, dan drama, termasuk dalam novel ini dihadapkan pada satu masalah sosial yang tidak pernah kunjung diatasi yaitu perkosaan, penindasan, aborsi, dan tindakan keji lainnya yang umumnya dilakukan oleh pihak berkuasa terhadap pihak lemah. Fenomena ini dalam realitas kehidupan sekarang di Indonesia semakin lama semakin menguat intensitas dan kualitasnya, sementara tidak banyak kasus-kasus seperti di atas dapat diungkap dan dituntaskan secara hukum oleh yang berwajib.

Representasi masalah-masalah ini menunjukkan tingkat emosi yang ada di kalangan masyarakat sangat tinggi, sementara daya serap rukhani sebagai penyeimbang emosi sangat kurang. Akibat dari keadaan demikian, pihak pelaku dan pihak korban banyak yang dirugikan sehingga ada usaha dari pihak berwajib atau pemerintah mencari kambing hitam secapatcepatnya. Kasus ini persis seperti digambarkan dalam novel ini, bagaimana lamban dan berbelitbelitnya pemerintahan Mesir dalam memproses ' $\mathrm{Si}$ Kumis' dalam teks novel di atas.

Ada dua pendekatan dalam menanggapi ketidakstabilan terhadap ideologi gender di atas. Yang pertama pendekatan kriminalitas, seperti diulas tadi pendekatan seperti ini mencari kambing hitam kepada 'oknum-oknum' yang dianggap mempunyai penyimpangan moral; biasa berbuat jahat, kejam, melanggar kode etik, dan sebagainya, seperti yang diperankan oleh 'Si Kumis' dalam novel ini. Sedangkan pendekatan yang kedua yaitu melihat bahwa kasus-kasus seperti ini sebagai sebuah gejala pertanda zaman, semacam sebuah peringatan akan dan telah terjadinya kemerosotan moral dalam masyarakat atau bahkan dianggap sebagai zaman kehancuran suatu rezim. 
Karya sastra mempunyai kewenangan sebebas-bebasnya untuk ikut berpartisipasi dalam mendukung, membentuk atau menggugat ideologi gender dalam masyarakat melalui modusmodus representasi khas dari karya itu sendiri. novel Ayat-Ayat Cinta dalam kasus tindakan pemerkosaan ini menggugat terhadap kebijakkan pemerintah setempat yang terkesan melindungi warganya dari jeratan hukum. Hukum harus ditegakkan dan berlaku kepada siapa pun, pribumi, pendatang, atau presiden sekali pun. Penegasan terhadap gugatan penindasan dan perkosaan ini dikuatkan lagi dengan ditampilkannya keterangan-keterangan lain dari kitab suci dan hadits nabi.

Dari dua kasus yang ditampilkan dalam novel Ayat-Ayat Cinta yang berhubungan dengan gagasan atau ideologi gender di atas dapat ditarik benang merah antara lain, pertama, gender dihadirkan dalam novel ini bukan merupakan pengetahuan yang secara alamiah didapatkan. Penulis yang mengungkapkan gagasannya lewat narator harus mengalami pendidikan dan berbagai macam pengalaman sosial untuk mengenali sejumlah aturan mengenai boleh dan tidaknya, atau pantas dan tidak pantasnya hubungan dengan sesama manusia yang dikategorikan mempunyai perbedaan jenis kelamin atau pun kelas. Kedua, novel ini menekankan ideologi gender bersifat plural dan cara pandang terhadap perbedaan adalah adanya perbedaan berlaku untuk semua kelompok sehingga kesamaan derajat yang bersifat fisik seluruh manusia secara umum adalah sama, tidak ada pembeda. Ketiga, novel ini menampilkan hubungan yang kompleks antara individu sebagai agen sosial dengan ideologi gender yang dianutnya, tidak selamanya wanita dijadikan korban dalam setiap modus penindasan, demikian pula sebaliknya tidak selamanya laki-laki sebagai kaum penindas.

\section{Ideologi Gender dalam Pandangan Islam}

Ajaran Islam memandang, segala sesuatu yang diciptakan Tuhan telah diatur berdasarkan kodrat. "Sesungguhnya segala sesuatu Kami ciptakan dengan qadar" (QS. Al-Qamar: 49). Para ahli fiqih mengartikan qadar sebagai ukuran dan sifat yang ditetapkan Tuhan bagi segala sesuatu, termasuk individu manusia. Dengan demikian, laki-laki dan perempuan sebagai individu dan jenis kelamin memiliki kodratnya masing-masing.

Adanya perbedaan antara laki-laki dan perempuan tidak dapat disangkal karena memiliki kodratnya masing-masing. Perbedaan tersebut paling tidak dari segi biologis. Al-Quran mengingatkan, "Janganlah kamu iri hati terhadap keistimewaan yang dianugerahkan Allah terhadap sebagian kamu atas sebagian yang lain. Laki-laki mempunyai hak atas apa yang diusahakannya dan perempuan juga mempunyai hak atas apa yang diusahakannya" (QS. An-Nisa': 32).

Ayat di atas mengisyaratkan tentang adanya perbedaan, dan bahwa masing-masing perbedaan memiliki keistimewaan. Namun demikian, ayat ini tidak menjelaskan apa keistimewaan dan perbedaan itu. Tetapi dapat dipastikan bahwa perbedaan yang ada tentu mengakibatkan fungsi utama yang harus mereka emban masing-masing. Di sisi lain, dapat pula dipastikan tiada perbedaan dalam tingkat kecerdasan dan kemampuan berfikir antara kedua jenis kelamin itu. Al-Quran memuji ulul albab yaitu yang berpikir tentang kejadian yang ada di langit dan bumi. Pikir dan zikir dapat mengantar manusia mengetahui rahasia-rahasia alam raya. Ulul albab tidak terbatas pada kaum laki-laki saja, tetapi juga kaum perempuan, karena setelah Al-Quran menguraikan sifat-sifat ulul albab ditegaskannya "Maka Tuhan mereka mengabulkan permintaan mereka dengan berfirman; "Sesungguhnya Aku tidak akan menyia-nyiakan amal orang yang beramal di antara kamu, baik lelaki maupun perempuan". (QS. Ali Imran: 195).

Jelas ayat di atas memandang bahwa kaum perempuan sejajar dengan laki-laki dalam potensi intelektualnya, mereka juga dapat berpikir, mempelajari kemudian mengamalkan apa yang mereka hayati dari zikir kepada Allah serta apa yang mereka pikirkan dari alam raya ini. Laki-laki dan perempuan sama di hadapan Allah. Memang ada ayat yang menegaskan bahwa "Para laki-laki (suami) adalah pemimpin para perempuan (istri)" (QS. An-Nisa': 34), namun kepemimpinan ini tidak boleh membawanya kepada kesewenangwenangan, karena dari satu sisi Al-Quran memerintahkan untuk tolong menolong antara laki-laki dan perempuan sementara pada sisi lain Al-Quran memerintahkan pula agar suami sebagai pemimpin dan istri sebagai yang dipimpin 
hendaknya mendiskusikan dan memusyawarahkan persoalan mereka bersama.

Sepintas terlihat bahwa tugas kepemimpinan laki-laki merupakan keistimewaan dan derajat tingkat yang lebih tinggi dari perempuan. Derajat dalam pandangan para mufassirin adalah kelapangan dada suami terhadap istrinya untuk meringankan sebagian kewajiban istri. Al-Quran secara tegas menyatakan bahwa laki-laki bertanggungjawab untuk memenuhi kebutuhan hidup keluarganya, karena itu, laki-laki yang tidak memiliki kemampuan material dianjurkan untuk menangguhkan perkawinan. Namun bila perkawinan telah terjalin dan penghasilan lakilaki tidak mencukupi kebutuhan keluarga, maka atas dasar anjuran tolong menolong yang dikemukakan di atas, istri hendaknya dapat membantu suaminya untuk menambah penghasilan.

Jika demikian halnya, maka pada hakikatnya hubungan suami dan istri, laki-laki dan perempuan adalah hubungan kemitraan. Hal ini dapat dimengerti mengapa ayat-ayat Al-Quran menggambarkan hubungan laki-laki dan perempuan, suami dan istri sebagai hubungan yang saling menyempurnakan yang tidak dapat terpenuhi kecuali atas dasar kemitraan. Hal ini diungkapkan Al-Quran dengan istilah ba'dhukum mim ba'dhi - sebagian kamu (laki-laki) adalah sebagian dari yang lain (perempuan). Istilah ini dikemukakan Al-Quran baik dalam konteks uraiannya tentang asal kejadian laki-laki dan perempuan, maupun dalam konteks hubungan suami istri serta kegiatan-kegiatan sosial.

Kemitraan dalam hubungan suami istri dinyatakan dalam hubungan timbal balik: "Istriistri kamu adalah pakaian untuk kamu (para suami) dan kamu adalah pakaian untuk mereka" (QS. AlBaqarah: 187), sedang dalam keadaan sosial digariskan: "Orang-orang beriman, laki-laki dan perempuan, sebagian mereka adalah penolong bagi sebagian yang lain, mereka menyuruh (mengerjakan yang ma'ruf) dan mencegah yang munkar" (QS. AtTaubah: 71).Pengertian menyuruh mengerjakan yang ma'ruf mencakup segi perbaikan dalam kehidupan, termasuk memberi nasehat atau saran kepada penguasa, sehingga dengan demikian, setiap laki-laki dan perempuan hendaknya mampu mengikuti perkembangan masyarakat agar mampu menjalankan fungsi tersebut atas dasar pengetahuan yang mantap. Mengingkari pesan ayat ini, bukan saja mengabaikan setengah potensi masyarakat tentang konsep laki-laki dan perempuan, tetapi juga mengabaikan petunjuk kitab suci.

\section{Ideologi Keagamaan}

Ayat-Ayat Cinta karya Habiburrahman El Shirazy merupakan sebuah novel bertemakan cinta sebagai pembangun jiwa. Dengan membaca dan menganalisanya, jiwa akan tersentuh betapa rumit, susah, terjal, sekaligus mudah dan menyenangkan sebuah cinta yang sesungguhnya. Cinta merupakan gagasan utama penulis untuk diangkat sebagai tema yang menonjol dan dihadirkan dalam setiap plotnya. Cinta yang dihadirkan Kang Abik, panggilan akrab penulis, adalah cinta yang dikelilingi dengan berbagai dogma ajaran agama Islam. Bukan hanya gagasan-gagasan tentang cinta, tetapi gagasan lainnya yang dihadirkan dalam novel ini diangkat dari landasan dan intisari ajaran keagamaan secara keseluruhan.

Gagasan yang diungkapkan penulis lewat novelnya ini menjadi sebuah aktualisasi diri dalam memenuhi kebutuhan dan motivasi penulis. Habiburrahman ingin mengajak umat, khususnya umat Muslim pada kebenaran cinta dan kehidupan islami secara benar dan proporsional dengan gaya bahasa yang bisa diterima. Selain sebagai aktualisasi diri, kebutuhan yang mendorong Habiburrahman menulis Ayat-Ayat Cinta adalah rasa aman. Habiburrahman mengambil setting Mesir karena ia pernah tinggal di sana memperdalam ilmu keagamaan selama empat tahun. Sebagai orang yang mengerti agama dan ingin menyebarkan ajarannya ke khalayak melalui sebuah karya, sudah tentu gagasan yang terkandung di dalamnya bernuansa keagamaan pula.

Berikut dituturkan beberapa gagasan atau ideologi keagamaan yang terkandung dalam novel Ayat-Ayat Cinta secara ringkas disertai dengan penjelasannya.

\section{Ta'aruf}

Ta'aruf sebagai istilah bahasa Arab bermakna perkenalan antara dua orang atau lebih baik laki- 
laki atau perempuan (Alkalali,1987:124). Ta'aruf yang dimaksudkan dalam pembahasan ini adalah perkenalan seorang laki-laki kepada perempuan atau sebaliknya sebagai sarana yang objektif dalam melakukan pendekatan ke arah perkawinan. Ta'aruf sangat berbeda dengan pacaran. Ta'aruf secara syar'i memang diperintahkan oleh Rasulullah Saw bagi pasangan yang ingin nikah. Perbedaan mendasar antara pacaran dengan ta'aruf terletak dari segi tujuan yang ingin dicapai dan manfaat yang ingin didapatkan dalam membina hubungan rumah tangga.

Jika tujuan pacaran lebih kepada kenikmatan sesaat, zina dan maksiat, maka ta'aruf jelas sekali tujuannya untuk mengetahui kriteria calon pasangan. Dalam pacaran, mengenal dan mengetahui hal-hal tertentu calon pasangannya dilakukan dengan cara yang sama sekali tidak memenuhi kriteria sebuah pengenalan. Ibarat seorang yang ingin membeli mobil second tapi tidak melakukan pemeriksaan, dia cuma memegang atau mengelus mobil itu tanpa pernah tahu kondisi mesinnya. Sedangkan ta'aruf adalah seperti seorang montir mobil ahli yang memeriksa mesin, sistem kemudi, sistem rem, sistem lampu dan elektrik, roda dan sebagainya. Bila ternyata cocok, maka barulah dia melakukan tawar menawar untuk memastikan pilihannya.

Ketika melakukan ta'aruf, seseorang baik pihak laki-laki atau perempuan berhak untuk bertanya yang mendetail, seperti tentang penyakit, kebiasaan buruk dan baik, sifat dan lainnya. Kedua belah pihak harus jujur dalam menyampaikannya. Karena bila tidak jujur, bisa berakibat fatal nantinya, terjadi pertikaian yang tidak pernah diharapkan. Dalam upaya ta'aruf dengan calon pasangan, pihak laki-laki dan perempuan dipersilahkan menanyakan apa saja yang kira-kira terkait dengan kepentingan masingmasing nanti selama mengarungi kehidupan. Tapi tentu saja semua itu harus dilakukan dengan adab dan etikanya. Tidak boleh dilakukan cuma berdua saja, harus ada yang mendampingi dan yang utama adalah wali atau keluarganya. Jadi ta'aruf bukanlah bermesraan berdua, tapi lebih kepada pembicaraan yang bersifat realistis untuk mempersiapkan sebuah perjalanan panjang berdua dalam ikatan pernikahan.
Narator yang menjadi tokoh utama dalam novel Ayat-Ayat Cinta, Fahri mengalami hal yang diuraikan di atas. Perasaannya berguncang saat akan bertemu dengan calon istri karena sebelumnya tidak pernah melihat wajah aslinya, ditutup dengan cadar, hanya kenal suara dan sorot matanya saja (AAC, 214).

\section{Poligami}

Poligami dalam Islam merupakan praktek yang diperbolehkan, tidak larang namun tidak dianjurkan. Islam memperbolehkan seorang pria beristri hingga empat orang istri dengan syarat suami harus dapat berbuat adil terhadap seluruh istrinya. Hal ini tercantum dalam Al Quran Surat an-Nisa ayat 3.

Dalam kitab Al- Iu'lu wal Marjan, karangan Abdul Baqi dijelaskan bahwa sikap beristeri lebih dari satu wanita yang dilakukannya adalah upaya transformasi sosial. Mekanisme beristeri lebih dari satu wanita yang diterapkan Nabi adalah strategi untuk meningkatkan kedudukan perempuan dalam tradisi feodal Arab pada abad ke-7 Masehi. Saat itu, nilai sosial seorang perempuan dan janda sedemikian rendah sehingga seorang laki-laki dapat beristri sebanyak mereka suka. Sebaliknya, Nabi membatasi praktek poligami, mengkritik perilaku sewenang-wenang, dan menegaskan keharusan berlaku adil dalam beristeri lebih dari satu wanita. Nabi Muhammad Saw marah besar ketika mendengar putrinya, Fatimah, akan dimadu oleh Ali bin Abi Thalib. Ketika mendengar kabar itu, Nabi pun langsung masuk ke masjid dan naik mimbar, lalu berseru:

"Beberapa keluarga Bani Hasyim bin alMughirah meminta izin kepadaku untuk mengawinkan putri mereka dengan Ali bin Abi Thalib. Ketahuilah, aku tidak akan mengizinkan, sekali lagi tidak akan mengizinkan. Sungguh tidak aku izinkan, kecuali Ali bin Abi Thalib menceraikan putriku, kupersilahkan mengawini putri mereka. Ketahuilah, putriku itu bagian dariku; apa yang mengganggu perasaannya adalah menggangguku juga, apa yang menyakiti hatinya adalah menyakitiku juga" (Abdul Baqi, t.t).

Penentang poligami kerap menggunakan hadits di atas untuk menolak dibolehkannya poligami, namun sebenarnya, hadits tentang 
kejadian yang sama dalam versi yang lebih lengkap menceritakan bahwa marahnya Nabi Muhammad Saw dikarenakan oleh calon yang hendak diperistri Ali adalah putri dari Abu Jahal, salah satu musuh Islam saat itu. Sesungguhnya Poligami lebih baik daripada berselingkuh atau berzinah dengan pelacur. Poligami itu halal, sementara selingkuh atau pelacuran itu haram. Ungkapan ini merujuk kepada Al Qur'an surat Anisa, ayat 3 di atas. Tetapi penentang poligami sering menggunakan ayat $\mathrm{Al}$ Qur'an ayat 129 , dari surat yang sama sebagai berikut.

Dalam ayat di atas Allah menegaskan bahwa manusia tidak akan dapat adil secara sempurna kepada istri-istrinya. Meski demikian bukan berarti melarang poligami, tapi menyuruh manusia agar tidak terlalu condong pada yang dicintai dan membiarkan yang lain terlantar. Adil yang dimaksud adalah adil dalam hal pemberian materi dan giliran.

Ada beberapa ulama, setelah meninjau ayatayat tentang poligami, mereka telah menetapkan bahwa menurut asalnya, Islam sebenarnya ialah monogami. Terdapat ayat yang mengandung peringatan agar tidak disalah gunakan poligami itu di tempat-tempat yang tidak wajar. Ini semua bertujuan supaya tidak terjadinya kezaliman. Tetapi, poligami diperbolehkan dengan syarat ia dilakukan pada saat-saat terdesak untuk mengatasi perkara yang tidak dapat diatasi dengan jalan lain. Atau dengan kata lain bahawa poligami itu diperbolehkan oleh Islam dan tidak dilarang kecuali jika dikhawatirkan bahawa kebaikannya akan dikalahkan oleh keburukannya. Jadi, sebagaimana talaq, poligami diperbolehkan karena hendak mencari jalan keluar dari kesulitan.

Dalam novel Ayat-Ayat Cinta, kekhawatiran akan tidak tertolongnya jiwa seseorang menjadi gagasan kuat penulis untuk dijadikan alasan seorang suami boleh melakukan poligami, bahkan merupakan suatu amal saleh jika melakukannya secara ikhlas. Demi kesembuhan Maria, Fahri menikahinya dalam suasana serba sulit, tetapi hati tetap tabah dan ikhlas (AAC, 378). Adegan dalam teks di atas menunjukkan betapa sempurnanya keimanan seorang istri, dan betapa beruntungnya seorang suami memiliki dua keberuntungan, dua istri salehah dan dua kepribadian yang sempurna dihiasi bingkaian syariat Islam.
Kalangan Barat menilai bahwa poligami sebagai kelemahan umat Islam dalam membatasi kebebasan berhubungan dan ketidak adilan. Novel ini menjawab keraguan Barat tersebut melalui uraian teks-teks religis realistis dan logis dalam realita kehidupan seperti dalam salah satu kutipan teks di atas tadi. Islam memperbolehkan umatnya berpoligami berdasarkan ayat-ayat syariat serta realita keadaan masyarakat. Ini berarti poligami tidak boleh dilakukan dengan sewenang-wenang, demi untuk mencapai kesejahteraan dan menjaga ketinggian budi pekerti kaum Muslimin.

\section{Terorisme}

Kata terorisme dalam bahasa Arab dikenal dengan istilah 'irhab'. Kata ini menurut tinjauan syari'at Islam, pada asalnya bukanlah bermakna kata yang dibenci. Bahkan kata ini merupakan kata yang mendapat porsi makna tersendiri didalam syari'at Islam (Rasjid, 2005: 121). Dalam Al Qur'an Allah berfirman menggunakan istilah kata ini. "Dan siapkanlah untuk menghadapi mereka kekuatan apa saja yang kamu sanggupi dan dari kuda-kuda yang ditambat untuk berperang (yang dengan persiapan itu) kamu menggetarkan (membikin irhab pada) musuh Allah" (Al-Anfal: 61).

Rasa gentar dan takut yang menyelinap di hati para musuh Islam, adalah ketakutan luar biasa, yang difirmankan Allah." Kelak Aku jatuhkan rasa takut ke hati orang-orang kafir" (Al-Anfal : 12) Dan juga disabdakan oleh Nabi Saw. "Aku ditolong dengan rasa takut (yang ditanamkan kepada musuh) sejak sebulan perjalanan" (H.R. Imam Bukhari, dalam Abdul Baqi). Jadi, kata irhab atau terorisme dalam Islam bukanlah terorisme dalam kenyataan yang terjadi akhir-akhir ini, dan bukan pula terorisme dalam kejadian mencekam yang problematis seperti sekarang ini.

Terorisme yang didengungkan selama ini adalah terorisme pesanan yang direkayasa oleh Barat agar mereka bisa menekan umat Islam sehingga semua aspek dan sendi kehidupan umat Islam bisa didikte mereka, baik sektor politik, ekonomi, perdagangan bahkan sampai pendidikan (http://swaramuslim.net). Banyak sekali fakta untuk membenarkan terorisme yang dimaksudkan oleh Barat adalah umat Islam yang taat beribadah, paham agamanya dengan baik, berjenggot, rajin 
ke mesjid, atau umat Islam yang membela tanah airnya dari jajahan bangsa asing seperti di Palestina, Irak, Afghanistan, Somalia dan sebagainya.

Jika yang dituduhkan Barat demikian, maka pantaslah seorang ulama dari Timur Tengah mengucapkan kata-kata yang sangat tegas, "jika mengamalkan ajaran Islam dengan benar dan membela tanah air disebut sebagai teroris, maka sayalah yang akan menjadi teroris pertama sekali"( Qutb, 1996:232).

Salah satu ungkapan di atas digagas penulis novel Ayat-Ayat Cinta dalam sebuah plot pertikaian anatar narator dengan warga Mesir di dalam sebuah metro atau bis. Metro yang penuh sesak dengan penumpang tiba-tiba berhenti di satu tempat pemberhentian untuk mengambil tiga orang penumpang berkewarganegaraan Amerika Serikat. Tidak satu pun dari warga Mesir yang ada dalam metro itu mempersilahkan duduk kepada salah satu warga Amerika yang terlihat kepayahan karena usianya sudah lanjut. Mereka sengaja memperlakukan demikian, supaya Amerika tahu bahwa negara Islam, khususnya Mesir tidak senang dengan tuduhan mereka; sebagai tindakan balas dendam.

Tiba-tiba muncul seorang wanita bercadar memberikan bantuan kepada wanita tua dari Amerika tersebut untuk duduk ditempatnya. Sikap wanita tersebutlah yang menjadi pemicu terjadinya pertikaian di dalam metro tersebut. Dalam keadaan terdesak oleh cemoohan warga Mesir di dalam metro, narator muncul dengan gagasannya membenarkan sikap wanita bercadar dan meluruskan permasalahan tentang bagaimana sebenarnya pandangan Islam terhadap Barat, dan bagaimana sebenarnya Islam bersikap terhadap tamu non Islam (AAC, 48).

Islam adalah agama damai dan penuh toleransi, agama yang menjunjung tinggi nilai kemanusiaan serta menentang pengrusakkan atau pembunuhan, baik dilakukan secara berkelompok seperti dalam sebuah jaringan atau terhadap individu. Dalam Islam, terdapat 5 hak asasi manusia yang tidak boleh diganggu oleh siapa pun dan dengan alasan apa pun, karena sangat dihormati dan dipelihara oleh agama Islam, yaitu agama, nyawa, harta, nasab dan kehormatan (Qutb, 1996:236). Islam berlepas diri dari kejahatan-kejahatan pengerusakan, teror, juga bunuh diri seperti yang terjadi di tanah air beberapa waktu yang lalu.

Siapapun yang melakukan pelecehan dan tindak kejahatan terhadap kelima hak asasi manusia tersebut maka tidak akan bisa diterima, dan Islam memberikan hukuman yang sangat berat terhadap pelakunya. Seperti yang difirmankanNya: "Barang siapa membunuh seorang manusia bukan karena orang itu membunuh orang lain (bukan karena qishash), atau bukan karena membuat kerusakan di bumi, maka seakan-akan ia membunuh manusia seluruhnya; dan barang siapa memelihara kehidupan seorang manusia, maka seakan-akan ia telah memelihara kehidupan manusia seluruhnya." (QS, Al-Maidah: 32).

Islam melarang menggunakan segala cara untuk meraih tujuan. Dalam suasana kecamuk perang sekali pun, Islam memberikan ramburambu dan etika berperang; tidak boleh membunuh orang yang telah menyerah, tidak boleh membunuh wanita, orang tua, anak kecil, tidak boleh merusak tanaman, atau tempat ibadah. Tawanan perang dalam Islam juga dijaga dan diperlakukan secara manusiawi (Qutb, 1996:239). Oleh karena itu, setiap tindak kekerasan, pembunuhan atau pemboman, maka tindakan itu tidak bisa ditolelir, tidak bisa diterima, siapapun pelakunya, apapun agamanya.

Adapun berkembangnya opini di media massa saat ini yang cenderung mengarahkan pelakunya dari umat Islam yang taat beragama, seakan membenarkan bahwa pelakunya identik dengan muslim yang shalih dan taat beragama, seolah orang yang taat beragama Islam maka ia sudah dekat dengan julukan teroris. Pada akhirnya, image ini akan menggiring opini public ke dalam sebuah paradigma berpikir bahwa terorisme itu memang ada dan dibenarkan dalam Islam. Pertanyaanya, benarkah terorisme ada dalam Islam?

Umat Islam sepatutnya bersatu-padu, berupaya membuktikan bahwa pengrusakkan, pemboman itu tidak dibenarkan dalam agama manapun, dan mengutuk tindakan tersebut. Lebih dari itu, umat Islam jangan mudah dipecah-belah, hanya gara-gara iming-iming materi, jabatan, atau dunia lainnya. Umat Islam harus ingat, teori politik belah bambu, satu kelompok diberi keluasaan dan 
kekuasaan, sedangkan kelompok yang lain ditindas dan dihancurkan. Umat Islam harus terus berupaya, bekerja keras untuk membuktikan dirinya sebagai pembawa misi 'Islam rahmatan lil'alamin'. Sekaligus juga harus memiliki benteng yang berlapis dari berbagai macam tipu-daya, adudomba dan konspirasi yang menyudutkan dan menghancurkan Islam dan umatnya, seperti yang digagaskan narator di atas tadi.

\section{Profesionalisme dalam Dakwah}

Profesionalisme dalam Islam dikenal sebagai 'ihsan' dalam segala perbuatan. Ia juga diidentikkan atau diacu dengan kata 'Bashirah'. Semakin luas dan tajam bashirah seseorang, akan semakin profesional menggeluti bidang kerjanya. Allah menciptakan kehidupan ini untuk menguji manusia siapa yang benar-benar professional dalam beramalnya. "Yang menjadikan mati dan hidup, supaya Dia menguji kamu, siapa di antara kamu yang lebih baik amalnya" (QS. AlMulk: 2).

Agar rasa dan sikap profesionalitas tampil, maka segala aktifitas seseorang harus diawali dengan sebuah kesadaran nawaitu yang benar dan diawali dengan 'taubatan nasuha' yang akan memperbaiki hubungan dengan Allah. Salah dan bergesernya niat akan turut mempengaruhi kinerja seseorang dan mengakibatkan kerja asalasalan, tidak sempurna dan cenderung apa adanya. Inilah rahasianya kenapa setiap amal dalam Islam harus didasari niat yang benar dan tulus karena Allah. Rasa takut akan pertanggungjawaban dakwah di hadapan Allah juga akan turut memperkuat keseriusan dan kejelasan dakwah seseorang.

Kualifikasi dan profesionalisme para da'i merupakan persoalan besar dalam dakwah yang harus diperhatikan dengan baik dan tidak boleh diabaikan dalam keadaan apa pun. Selanjutnya Ibnu Katsir merumuskan beberapa bangunan profesionalisme dakwah yang ternyata diawali dengan persoalan ilmu: Memiliki landasan ilmu atas apa yang ia sampaikan yang diteruskan secara implementatif dengan sikap jujur dan benar terhadap apa yang ia sampaikan. Disinilah kedudukan ilmu sebagai pondasi dalam beramal.

Seorang yang profesional adalah seorang yang tekun, sabar dan tahan godaan, senantiasa dinamis dan mencari kreatifitas baru dalam berdakwah, karena memang ia tidak akan pernah setuju dan rela jika dakwah ini vakum, berjalan di tempat dan tidak mendapat tempat di hati umat (www.uad.ac.id/in/berita-umum). Contoh paling fenomenal adalah Muhammad Saw. Nabi ketika akan hijrah ke Medinah sempat ditawari unta secara cuma-cuma oleh sahabat Abu Bakar Al Shidiq, tetapi nabi tidak menerima unta itu secara cuma-cuma melainkan membayarnya sesuai dengan harga di pasaran saat itu. Nabi tidak ingin kepentingan dakwah dibebankan kepada Abu Bakar, sedangkan dia adalah umatnya.

Tantangan yang dihadapi umat dalam menyebarkan ajaran Islam pada masa nabi dan masa kini tentu berbeda, tetapi nilai Islam berlaku sepanjang zaman. Situasi zaman nabi dan zaman sekarang dalam problematik keagamaan tingkatannya sangat jauh berbeda, karena interprestasi umat pada masa kini cenderung berkembang, dan nabi telah mencontohkan berbagai permasalahan itu dengan suri tauladan.

Sikap-sikap seperti nabi di atas dalam menjalankan dakwah Islam dengan profesionalitas tinggi tanpa mengandalkan umat disinggung sangat jelas dalam adegan novel AyatAyat Cinta, dalam halaman 107.

\section{Nilai-Nilai Estetik dalam Novel Ayat-Ayat Cinta}

Alur Cerita

Alur cerita yang dipakai dalam novel Ayat-Ayat Cinta adalah alur maju, walaupun terdapat flashback yang dialami oleh tokoh utama, Fahri. Tetapi flashback tersebut sengaja dimunculkan untuk memperkuat karakterisasi Fahri. Flashback yang ditampilkan cenderung memutar kembali nuansa pikiran dan pengalaman Fahri sewaktu di Indonesia, atau pengalaman-pengalaman dia dalam menghadapi suatu keadaan selama tinggal di Mesir. Pada dasarnya, ada tiga alur besar dalam novel Ayat-Ayat Cinta ini. Alur cerita yang pertama adalah rangkaian-rangkaian awal kejadian di keseharian Fahri di flat tempatnya berkumpul dengan teman-teman prianya, dengan Maria, dan dengan Nurul.

Alur cerita yang kedua adalah merupakan adegan terpenting dan penentu alur-alur sebelum dan sesudahnya, yaitu Fahri bertemu dengan 
Aisha di Metro ketika hendak pergi talaqqi. Pertemuan antara Fahri dan Aisha ini disebut sebagai titik awal cerita menuju puncaknya. Pertemuan ini menjadi penyebab terjadinya pernikahan keduanya pada cerita selanjutnya. Sehingga alur novel ini saling berhubungan dan menunjukkan sebab akibat. Fahri nikah dengan Aisha karena mereka bertemu pertama kali di Metro, dan awal pertemuan itu menyebar kepada tema lain yang saling berhubungan.

Alur ketiga adalah adegan ketika berbagai masalah muncul yang merupakan akumulasi dari kedua alur sebelumnya dimana klimaksnya terjadi yaitu ketika Fahri dipenjara. Jalannya semua alur disampaikan dengan sangat 'rendah hati'. Penuh dengan kata-kata yang mengkiaskan gaya bahasa 'kesabaran', runut, sangat manis, dan sangat islami. Hal inilah yang menjadi media penyampaian pesan-pesan moral melalui karakterisasi Fahri yang menjadi tokoh sentral yang menguasai semua alur.

Fahri tak harus berkata bahwa 'saya adalah orang rendah hati dan sabar', tetapi interaksi dan bagaimana tokoh tersebut dibangun, cukup mengatakan bahwa dia adalah orang yang demikian. Fahri tak pernah bilang bahwa dirinya adalah orang yang saleh, tetapi setiap gerakgeriknya terhadap tokoh lain sangat merepresentasikan bahwa dia sebisa mungkin tidak melanggar apa yang diperintahkan dalam semua hukum-hukum baku dalam Islam. Terlihat sekilas, karakterisasi Fahri sangatlah 'penuh', tidak cacat sedikit pun.

Tetapi pada perjalanan setengah cerita, permasalahan sengaja dimunculkan untuk memberikan pesan bahwa plot sebelumnya belum bisa membuat Fahri menjadi tokoh yang kuat. Permasalahan seperti penokohan tokoh Aisha yang ingin mengambil jatah kekuasaan cerita dengan ditokohkan menjadi seorang yang kaya raya, tak bisa menggoyahkan pegangan Fahri atas semua alur yang telah dibangun pengarang. Fahri tetap menjadi tokoh sentral yang kuat, memegang peranan dalam cerita. Aisha mengalah dan mundur. Begitupun dengan klimaks yang terjadi ketika Fahri harus dijebloskan ke penjara, disiksa dengan sangat keras, terpisahkan dari sumber kekuatannya, yaitu tokoh Aisha, tetapi Fahri tetap keluar sebagai tokoh kuat yang mengatur jalannya plot cerita. Dari semua usaha penokohan yang dibangun, Fahri tetap menjadi tokoh sentral yang menguasai seluruh cerita.

\section{Tokoh Cerita}

Dalam novel Ayat-Ayat Cinta ini terdapat tokoh utama dan tokoh bawahan. Tokoh utama dalam novel ini adalah Fahri bin Abdillah seorang mahasiswa yang cerdas dan berbudi pekerti luhur kepada setiap orang. Ia berusaha menggapai gelar masternya di Universitas Al-Azhar, Cairo, Mesir. Hidup Fahri dikejar oleh target karena keluarganya telah mengorbankan segalanya, termasuk sawah warisan kakeknya, agar dia bisa sekolah di Mesir. Fahri berusaha memenuhi target yang digambarkan dalam peta hidupnya, berjuang melawan teriknya udara Mesir dan keterbatasan dana. Ia juga memiliki target untuk menikah dengan perempuan yang salehah untuk menyempurnakan agamanya saat dia menyelesaikan tesis magisternya.

Sosok Fahri yang sangat disegani oleh setiap orang yang mengenalnya dikarenakan dia adalah seorang muslim yang taat dan memiliki karakter yang dinamis dan pluralis dalam pergaulan. Fahri juga seorang pemuda yang sederhana, cerdas dan bijaksana. Dia menguasai bahasa Arab, Jerman, dan Inggris sehingga selama belajar di Mesir ia melakukan terjemahan kitab-kitab hadits, tafsir Al-qur'an ataupun kitab-kitab dari para ulama-ulama Mesir yang terkenal.

Dari gambaran yang disampaikan di atas dapat diketahui bahwa tokoh Fahri ditampilkan sebagai sosok yang berwatak datar atau istiqamah. Ia mempunyai sifat sederhana, pemurah, supel, dan ramah tetapi cerdas, sehingga mudah diingat oleh pembaca. Penulis novel ini menggambarkan tokoh Fahri secara analitik, yaitu pengarang dengan ceritanya menjelaskan berbagai segi dari tokoh itu.

Selain tokoh utama Fahri, novel ini mempunyai beberapa tokoh bawahan, di anataranya sebagai berikut.

\footnotetext{
Aisha

Seorang gadis cantik, bercadar, besar dan lahir di Jerman, anak seorang pengusaha swalayan kaya di negeri itu, bernama Rudolf Greimas Omar. Ia adalah warga keturunan Turki berdarah Palestina.
} 
Belajar ke Mesir untuk melengkapi tesisnya dalam bidang fiqh, dan tinggal bersama pamannya, Eqbal Hakan Ebrakan. Prilaku Aisha dilukiskan sebagai tokoh yang bersifat moderat, berpandangan tidak sempit, berwawasan sangat luas, seorang istri yang romantis dan setia, bahkan kesetiaannya pada suami dikukuhkan dengan pemberian izin bagi suami untuk berpoligami.

Selain digambarkan sebagai tokoh yang moderat dan istri yang setia, ia adalah sosok wanita yang tangguh membela dan menyiarkan syariat Islam dalam berbagai aktivitasnya. Keluhuran nilai dari prilakunya semata demi menyebarkan dakwah. Sifat dan watak Aisha ini sudah dibentuk dan diajarkan sejak kecil dari ibunya. Pengalaman pahit waktu ditinggalkan ibu tercinta, menjadikannya pemicu untuk selalu berbuat yang terbaik demi keluarga, walaupun salah satu keluarganya, sang ayah telah kembali inkar dari Islam, demi rasa tanggungjawab ia berusaha meluruskannya kembali.

\section{Maria}

Tokoh ini dianggap oleh tokoh utama, Fahri sebagai sosok wanita yang aneh. Maria lebih suka disebut Maryam, sesuai dengan nama yang tertera pada salah satu surat Al-Quran. Ia adalah putri sulung dari pasangan keluarga Kristen Koptik yang terkenal ketaatan ibadahnya, yaitu Tuan Boutros Rafael Girgis dan Madame Nahed. Walaupun beragama Kristen Koptik, Maria hafal beberapa surat Al-Quran, memahami beberapa kandungan nilai yang tercantum di dalamnya. Fahri menganggap kebiasaan Maria mendengarkan suara azan, melantunkan ayat-ayat suci Al-Quran dan kebiasaan umat Islam lainnya, adalah sesuatu yang aneh. Keanehan memang tidak ada hubungannya dengan hidayah. Hidayah bisa datang dan pergi tanpa diprediksi dan diharap. Masalah hidayah inilah yang menjadi keanehan Fahri.

Sosok Maria dalam kehidupan kesehariannya adalah wanita yang sopan, ramah, dan tidak seronok dalam penampilan. Ia mempunyai kebiasaan menitipkan untuk dibelikan sesuatu kalau Fahri mau keluar flat. Kebiasaan ini sebagai pertanda ada rasa perhatian yang lebih dan mengharap balasannya.
Sampai akhirnya terjadi suatu peristiwa yang sangat memukul perasaannya. Orang yang dikaguminya selama ini telah melangsungkan pernikahan dengan seorang putri cantik dan kaya raya keturunan Jerman. Peristiwa ini tentunya sangat mengganggu pikiran dan bahkan kesehatannya. Karena rasa cintanya yang sangat mendalam kepada Fahri, beberapa hari setelah mendengar berita itu ia koma, tidak sadarkan diri dalam waktu yang sangat lama. Kedua orang tuanya merasa putus asa, tidak ada satu pun dokter yang mampu mendeteksi penyakit lahirnya. Sampai akhirnya dokter menyarankan kepada keluarga, membawa Fahri, sosok yang sering diigaunya, untuk dibawa dan dipertemukan dengannya. Kehadirannya sangat membantu untuk merangsang gairah hidup dan daya ingatnya.

Begitu berartinya sosok Fahri bagi Maria, diketahui oleh Aisha, istri Fahri. Dengan rasa tulus dan ikhlas demi ibadah dan menolong jiwa Maria dengan mengeyampingkan ego, Aisha menyarankan suaminya untuk menikahi Maria. Namun masih ada satu ganjalan bagi Fahri menikahinya, yaitu Maria masih beragama Kristen Koptik, suatu keyakinan yang berbeda dengannya.

\section{Noura}

Nama yang indah dan cantik ini dalam kenyataannya bertolak belakang dengan nasibnya. Noura, seorang siswi di tingkat akhir Ma'had Al-Azhar ini berada dalam kekangan, kurungan, dan siksaan Bahadur dan istrinya, Madame Syaima. Sikap keras Bahadur dan keluarganya kepada Noura sebenarnya telah menjadi rahasia umum di lingkungan sekitarnya. Pernah tetangganya akan melaporkan tindakan tidak berprikemanusiaan Bahadur kepada Noura, tetapi ia selalu menolaknya, mengalah dan mengakui bahwa ini semua adalah kesalahannya, menutupi kesalahan Bahadur yang telah dianggap sebagai orang tuanya sendiri.

Puncak penyiksaan Bahadur kepada Noura terjadi pada suatu malam, karena ia menolak untuk dijual pada hidung belang. Ia diseret ke tengah jalan dan dimaki-maki kata kasar. Kejadian ini telah mengundang iba Fahri untuk menolongnya. Lewat Maria, Fahri menolongnya dan ditipkan di satu tempat yang aman, tempat asrama 
mahasiswi Indonesia di Nasar City.

Keadaan di Nasr City kurang begitu aman, sehingga ia dititipka di kampung salah satu gurunya Fahri, Syekh Akhmad. Dalam pengawasannya ia berangsur sehat jasmani dan rukhaninya, mempunyai rasa kepercayaan dan semangat hidup yang tinggi. Syekh Ahmad akhirnya mengetahui, bahwa Noura bukan anak kandung Bahadur. Ia tertukar waktu dilahirkan di rumah sakit dengan keluarga Tuan Adel dan Madame Yasmin, seorang keluarga terhormat yang berpropesi sebagai dosen. Noura diterima tinggal dirumah keluarga itu dengan penuh rasa kasih sayang.

Sebaliknya Noura malu tinggal di rumah itu, karena perutnya membesar, hamil, diperkosa oleh ayah angkatnya Bahadur. Untuk menghilangkan rasa malu itu, kepada ayahnya Noura mengaku telah diperkosa oleh orang yang dicintainya, Fahri. Suatu pengakuan yang mengakibatkan Fahri masuk penjara. Namun kebohongan itu terkuak juga, berkat kesaksian Maria di pengadilan. Fahri pun dibebaskan dari segala tuduhan, dan Noura mengaku di depan persidangan bahwa semua pengakuannya adalah bohong. Hal itu dilakukan untuk menutupi rasa malu di depan keluarga dan mengharapkan Fahri menikahinya. Ia menyesal dan minta maaf kepada semua orang yang telah membantunya keluar dari cengkraman Bahadur.

\section{Nurul Azkiya}

Ia diceritakan sebagai seorang mahasiswi Indonesia yang kuliah di Al-Azhar. Selain sebagai Mahasiswa, ia seorang ketua Wihdah yang ulet dan rajin, sebuah induk organisasi mahasiswi Indonesia di Mesir. Selain ulet, pribadinya digambarkan penulis sebagai sosok yang penuh kesibukan dan pengabdian dalam berbagai hal, tanpa pandang jabatan. Hal ini terlihat ketika setiap hari minggu ia selalu menyempatkan waktunya untuk mengajar anak-anak membaca Al-Quran di KBRI Mesir.

Seperti tokoh Maria dan Noura, cinta nurul kepada Fahri sangat besar sekali, dan tidak pernah diungkapkan secara langsung. Perasaannya selalu dipendam, hingga akhirnya menimbulkan kekecewaan. Kekecewaan Nurul berbeda dengan kekecewaan Maria dan Noura. Kalau Noura diwujudkan dalam penghianatan dengan fitnah, Maria dipendam hingga koma, sedangkan kekecewaan Nurul diungkapkan lewat sebuah surat ditujukan langsung kepada Fahri. Karena cintanya yang sangat kuat, ia meminta Fahri mengawininya sebagai istri kedua. Tentu saja ini ajakan yang sangat mengejutkan dan memberatkan bagi Fahri, karena ia telah berjanji setia tidak akan menghianati istrinya, Aisha. Andaikan perasaan Nurul diungkapkan sebelum Fahri menikah, atau bahkan berbarengan dengan ungkapan cinta Aisha, Fahri mengungkapkan sendiri lebih memilih Nurul. Alasan ini yang mengakibatkannya rela untuk menjadi istri kedua Fahri.

\section{Metafora}

Metafora adalah bahasa kiasan seperti perbandingan, namun tidak menggunakan kata-kata pembanding seperti 'bak', 'bagai', 'laksana', dan 'serupa'. Metafora juga melihat sesuatu dengan perantaraan benda lain sebagai pembanding (Pradopo, 1987: 66). Novel Ayat-Ayat Cinta cukup banyak menggunakan metafora. Berikut beberapa kutipan diantaranya.

Aku memandang ke arah Aisha, pada saat yang sama dua matanya yang bening di balik cadarnya juga sedang memandang ke arahku. Pandangan kami bertemu. Dan ces! Ada setetes embun dingin menetes di hatiku. Kurasakan tubuhku bergetar. Aku cepat-cepat menundukkan kepala. Dia kelihatannya melakukan hal yang sama (El Shirazy. "Pertemuan!", Ayat-Ayat Cinta, 2008, 213). Yang ada di depanku ini seorang bidadari ataukah manusia biasa. Mahasuci Allah, Yang menciptakan wajah seindah itu. Jika seluruh pemahat paling hebat di seluruh dunia bersatu untuk mengukir wajah seindah itu tak akan mampu. Pelukis paling hebat pun tak akan bisa menciptakan lukisan dari imajinasinya seindah wajah Aisha. Keindahan wajah Aisha adalah karya seni mahaagung dari Dia Yang Mahakuasa (El Shirazy. "Pertemuan!", Ayat-Ayat Cinta, 2008, 215).

Bahasa metafor biasanya dimunculkan atau diucapkan seorang tokoh dalam keadaan kondisi jiwa yang galau atau dalam keadaan kasmaran cinta. Hal ini terlihat dari paparan tokoh Fahri yang sedang dimabuk cinta, mengagumi kecantikan 
calon istrinya dengan ucapan yang seolah berlebihan dan tidak masuk akal. Tetapi itulah gaya bahasa bisa melukiskan keadaan jiwa seseorang. Kecantikan Aisha sangat mengagumkan, bahkan dapat menimbulkan gairah hidup, sehingga kecantikannya tidak akan ada yang menandinginya, sama seperti tukang pahat atau tukang ukir ingin mengukir wajahnya tidak akan bisa. Dengan gairah cinta yang tulus Fahri sudah bulat untuk membangun masa depan yang menjanjikan bersama Aisha.

\section{Kosakata}

Kata adalah modal pengarang yang paling mendasar, sehingga dapat membentuk sebuah susunan kalimat yang harmonis susunannya. Dengan kata lain, seorang pengarang akan mengekspresikan dirinya lewat kata-kata dalam karyanya secara bebas tanpa batas-batas mendasar tentang kaidah kebahasaan. Di sisi lain, seorang pembaca menikmati karya sastra juga lewat perantaraan kata. Dengan demikian, kosakata atau perbendaharaan kata itu merupakan sesuatu yang penting dan utama dalam menulis karya sastra.

Dalam novel Ayat-Ayat Cinta ada beberapa jenis kosakata yang digunakan pengarang, antara lain, kosakata sehari-hari, kosakata bahasa daerah, dan kosakata bahasa asing, dalam hal ini banyak digunakan kosakata bahasa Arab.

\section{Simpulan dan Saran Simpulan}

Dari uraian di atas yang membahas ideologi dalam novel Ayat-Ayat Cinta karya Habiburrahman El Shirazy dapat diambil beberapa simpulan sebagai berikut. Pertama, gagasan-gagasan utama dalam novel Ayat-Ayat Cinta adalah Al-Quran dan Sunnah. Tokoh dan alur cerita dalam novel tersebut dikondisikan dalam beberapa permasalahan keagamaan, diantaranya bagaimana seorang muslim berpacaran, cara mempergauli istri, sikap Islam terhadap Barat, perlakuan Islam terhadap perempuan, Islam memandang tentang poligami, dan lain seba-gainya. Semua permasalahan yang dimunculkan tersebut direpresentasikan lewat cerita kesalehan dan kepintaran tokoh Fahri dalam menngatasi semua permasalahan berdasarkan ajaran Islam. Kedua, gagasan keagamaan dari novel Ayat-Ayat Cinta dihadirkan penulis dengan cara penuturan tokoh aku, yaitu Fahri. Tokoh ini sangat besar peranannya terhadap tokoh-tokoh lain, karena selain sebagai penutur, ia sekaligus sebagai pemain. Ketiga, nilai estetika yang menonjol dari novel Ayat-Ayat Cinta meliputi alur cerita, tokoh atau penokohan, gaya bahasa atau metafora, kosakata bahasa sehari-hari, kosakata bahasa daerah, dan kosakata bahasa asing.

\section{Saran}

Salah satu instrumen pendukung mutu pendidikan Nasional adalah pelajaran Bahasa dan Sastra Indonesia yang masuk dalam kurikulum berbasis kompetensi. Sastra sudah saatnya tidak menjadi sisipan pelajaran Bahasa Indonesia di sekolah. Secara tidak langsung dapat dipastikan kurikulum berbasis kompetensi hanya slogan belaka apabila pembelajaran sastra di sekolah diabaikan. Pendidikan bermutu tidak selamanya memerlukan biaya yang besar, tetapi ia dapat dicapai dengan sebuah sistem yang mapan dalam bingkaian ideologi yang jelas dan terukur.

Sebuah karya sastra diciptakan pengarang untuk memberi gambaran yang sesungguhnya tentang realita kehidupan melalui imajinasi. Imajinasi dalam karya sastra dapat diciptakan dari fenomena yang muncul di masyarakat. Salah satu fenomena yang menarik dari novel ini adalah kegigihan seseorang dalam menempuh dunia pendidikan, bisa berhasil dengan gemilang di tengah keterbatasan materi serta timbulnya tantangan modernitas sebagai efek global tanpa meninggalkan kultur budaya dan moral. Walaupun tema percintaan islami lebih ditonjolkan dalam novel ini, tetapi nilai budayanya dapat dijadikan masukkan bagi pemerintah dalam mengembangkan mutu pendidikan.

Tema yang dihadirkan sebuah karya sastra memang imajinatif, tetapi ideologi yang melatarbelakanginya adalah gagasan cemerlang yang bersumber dari rujukan nyata dan bisa dijadikan cermin dalam mengambil kebijakan bagi kemajuan bangsa. Sedangkan nilai estetis dari sebuah karya sastra bisa dijadikan sebagai hiasan yang bermetafor dalam melaksanakan sebuah kebijakan sehingga dapat dicerna pembaca karya dan masyarakat luas. 


\section{Pustaka Acuan}

Abdul Baqi, M. Fuad. Tanpa tahun Al- lu'lu wal marjan/terjemahan Surabaya: PT Bina Ilmu.

Alkalali, Asad M. 1987. Kamus Indonesia Arab Jakarta: Bulan Bintang.

Budianta, Melani. 1998. Sastra \& Ideologi Gender. Jakarta: majalah Horison. ( no. 4, th XXII, edisi April). El Shirazy, Habiburrahman. 2008. Ayat-Ayat Cinta. Jakarta: Republika.

Qutb, Muhammad. 1996. Tafsir Islam Atas Realitas Jakarta: Yayasan SIDIK.

Rasjid, Sulaiman. 2005. Fiqh Islam Bandung: Sinar Baru Algensindo.

Roekminto, Fadjar S. 2008. Haruskah sastra berideologi? Seminar Hiski 2008 di Batu, Malang.

Santosa, Pudji. 1987. Teori Sastra. Madiun: FPBS - JPBI IKIP Press.

Tim Al-Quran. 1993. Al-Quran dan Terjemahannya Jakarta: Departemen Agama Republik Indonesia. http://id.wikipedia.org/ "Sastra dan Ideologi" diakses tanggal 5 Agustus 2009.

www.uad.ac.id/in/berita-umum "Pemimpin-amanah" diakses 12 Oktober 2009.

http://swaramuslim.net/more.php?id "Islam dan Terorisme" diakses 30 Oktober 2009.

http://violetatniyamani.blogspot.com2008 "Gender dalam Perspektif Islam" diakses 8 November 2009. 